\title{
Protein profile as a quality indicator of cryopreserved semen from Tambaqui Colossoma macropomum (Cuvier, 1818)
}

\author{
J. M. Galo ${ }^{a *}$ (D), D. P. Streit-Jr. ${ }^{b}$ (D), C. D. Corcini ${ }^{c}$ (D), A. S. Varela-Jr. ${ }^{d}$ (D), R. D. Jardim ${ }^{d}$ \\ and R. P. Ribeiro
}

anstituto Federal de Educação, Ciência e Tecnologia de Rondônia - IFRO, Campus Ariquemes, Rodovia RO-257, Km 13, CEP 76878-899, Ariquemes, RO, Brasil

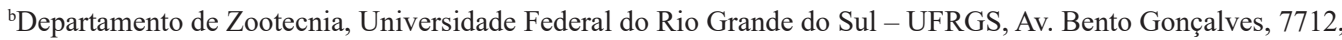
CEP 91540-000, Porto Alegre, RS, Brasil

'Faculdade de Veterinária, Universidade Federal de Pelotas - UFPEL, Rua Gomes Carneiro, 01, Centro, CEP 96010-900, Pelotas, RS, Brasil

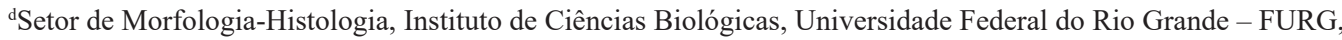
Av. Itália, s/n, Campus Carreros, Prédio 06, CEP 96203-000, Rio Grande, RS, Brasil

'Departamento de Zootecnia, Universidade Estadual de Maringá - UEM, Av. Colombo, 5790, CEP 87030-121, Bairro Zona 07, Maringá, PR, Brasil

*e-mail: juliana.galo@ifro.edu.br

Received: January 28, 2019 - Accepted: July 16, 2019 - Distributed: November 30, 2020

(With 2 figures)

\begin{abstract}
The aim of this study was to evaluate the association between proteins in the seminal plasma of tambaqui Colossoma macropomum (Cuvier, 1818) with seminal quality indicators after thawing. The semen was cryopreserved with a dilution based on BTS with $8 \%$ DMSO. A $200 \mu \mathrm{L}$ sample of semen from each animal was diluted in $800 \mu \mathrm{L}$ BTS, centrifuged at $800 \mathrm{rpm}$, and the supernatant was cryopreserved to further analyze of the protein profile of seminal plasma through one-dimensional electrophoresis (SDS-PAGE). After 15 days of cryopreservation, a cryopreserved semen straw was thawed to analyze both qualitative and quantitative parameters. When considering all collections, the SDS-PAGE identified 15 protein bands in the seminal plasma of tambaqui. When the interaction (presence or absence) between proteins observed in the seminal plasma and the post thawed spermatic parameters was evaluated, we observed a great influence of the presence of proteins on spermatic quality. A greater $(\mathrm{P}<0.05)$ fertilization rate was observed with the presence of proteins $12,34,44,85$, and $90 \mathrm{kDa}$. Proteins in seminal plasma of tambaqui influenced the spermatic quality after thawing, and thus, they can be utilized as an indicator of sperm quality, especially the proteins with a molecular weight $\leq 50 \mathrm{kDa}$.
\end{abstract}

Keywords: Colossoma macropomum, cryopreservation, spermatic motility, proteins, fertilization rate.

\section{Perfil protéico como indicador qualitativo do semen criopreservado de Tambaqui Colossoma macropomum (Cuvier, 1818)}

\section{Resumo}

O objetivo desse estudo foi de avaliar a associação entre a presença de proteínas no plasma seminal do tambaqui Colossoma macropomum (Cuvier, 1818) com indicadores de qualidade seminal pós-descongelamento. O semen foi criopreservado com diluidor a base de BTS com 8\% DMSO. Uma amostra de $200 \mu \mathrm{L}$ de semen de cada animal foi diluída em $800 \mu \mathrm{L}$ de BTS, e centrifugada em $800 \mathrm{rpm}$, e somente o sobrenadante foi criopreservado para posterior análise do perfil proteico do plasma seminal, através da eletroforese unidimensional (SDS-PAGE). Decorridos 15 dias da criopreservação, uma palheta com semen criopreservado foi descongelado para análise dos parâmetros quali-quantitativos. Considerando todas as coletas, o SDS-PAGE identificou 15 bandas proteicas no plasma seminal do tambaqui. Quando se avaliou a interação (presença ou ausência) das proteínas encontradas no plasma seminal, com os parâmetros espermáticos pós-descongelamento, observou-se grande influência da presença das proteínas na qualidade espermática. Observou-se maior taxa de fertilização $(\mathrm{P}<0,05)$ com a presença das proteínas $12,34,44,85$ e $90 \mathrm{kDa}$. As proteínas do plasma seminal de tambaqui influenciaram na qualidade espermática após descongelamento, podendo ser utilizadas como indicadores para a qualidade espermática após descongelamento, principalmente as proteínas com peso molecular $\leq 50 \mathrm{kDa}$.

Palavras-chave: Colossoma macropomum, criopreservação, motilidade espermática, proteínas, taxa de fertilização. 


\section{Introduction}

Gamete conservation is an important tool for fish reproduction and of great interest for fish-farming (Magnotti et al., 2018). Also, it facilitates the transport of genetic material between laboratories in a country and in another countries, as well as a greater caution to prevent disease transmission, thereby allowing for new strain introductions with a low risk of pathogens in cultivated fishes (Tiersch, 1995). Growing interest in improving the technique has led to an increase in the number of studies on this subject (Tiersch, 2011; Maria and Carneiro, 2012).

When considering the effect of the freezing process on semen quality, the study of techniques to identify variation in response to freezing among several males and to develop tests to find the freezing potential becomes important. Thus, the protein composition of the seminal plasma should be deemed as an important factor that influences fertility in males (Autiero et al., 1991; Strzeżek et al., 2005) a glycoprotein in the seminal plasma with a high molecular weight $(120 \mathrm{kDa})$ was identified as a factor in the immobilization of spermatozoids (Mochida et al., 1999, 2002) in Nile tilapia (Oreochromis niloticus). Some of these proteins can be used as biochemical markers to identify individuals with higher or lower potential for fertility and freezing of semen (Jobim et al., 2004; Zilli et al., 2005; Asadpour et al., 2007).

The seminal plasma, in the majority of the teleost, is a product that is synthesized in the scrotum and spermatic ducts (Lahnsteiner et al., 1994) which should be considered since several species did not present with accessory glands. Some components of the seminal plasma are not secreted, but they can be produced by spermatic cells during decomposition (Ciereszko et al., 2000). The seminal plasma of teleost fishes is of great importance in the sperm physiology, because its mineral composition inhibits the spermatic motility inside of the sperm ducts, provides an isotonic and equilibrated environment for the sperm (Morisawa and Suzuki, 1980; Cosson et al., 1999), as well as monosaccharides and lipids for energetic resources of the spermatozoids (Lahnsteiner et al., 1994). According to Loir et al. (1990), proteins are the greatest organic component in the seminal fluid of teleost fish. Recent studies highlighted the importance of plasma proteins for spermatozoids. For example, in rainbow trout (Oncorhynchus mykiss) where the sperm were stored in a saline solution similar to the seminal fluid composition, the motility rate and swimming speed, which can be activated, increased when the stored solution contained seminal plasma proteins, thereby indicating that these proteins establish and enable the sperm (Lahnsteiner et al., 2004).

When seminal plasma is incorporated into cryopreservation process, it reduces the harmful effects of other cryoprotectants and exerts a cryoprotectant and antioxidant activity which protects sperm function in fish (Alvarez et al., 2008; Figueroa et al., 2017). A series antioxidant substances are found in the seminal plasma of freshwater fish (ascorbic acid, carnitine, glutathione, methionine, tacopheryl acid and uric acid) as well as oxidative defence enzymes (catalase, glutathione reductase, peroxidase and superoxide dismutase) which could help preserving the motility and fertilising capacity of this cells (Lahnsteiner, 2007b, 2009; Lahnsteiner and Mansour, 2010; Lahnsteiner et al., 2010)

Currently, the tambaqui Colossoma macropomum (Cuvier, 1818) is the endemic species that is the most highly produced in Brazil (Brasil, 2013). The freezing of semen from this species as a function of its commercial importance has been studied, and the protocol of cryopreservation was defined in the study by Varela Junior et al. (2012).

This study was conducted to identify the association between the presence of proteins in the seminal plasma of C. macropomum with indicators of seminal quality after thawing.

\section{Material and Methods}

\subsection{Animals and experiment}

Twenty-seven males $(6.4 \pm 0.4 \mathrm{~kg}$ and $4 \pm 2$ years $)$ and six females $(8.3 \pm 0.5 \mathrm{~kg}$ and $6 \pm 2$ years $)$ of tambaqui (C. macropomum) were kept in nurseries under ambient conditions and were fed with a commercial ration containing $36 \%$ crude protein and 2,900 kcal of digestible energy $\mathrm{kg}^{-1}$ of ration. During the reproductive period, the semen was obtained by inducting the males with extract of pituitary hormone from carp (PHC; 5.5 and $2.5 \mathrm{mg}$ PHC kg-1 fishes, females and males, respectively). The chemicals were procured from Sigma Aldrich, St. Louis, MO, USA.

\subsection{Semen collection and analysis}

Seven hours after the hormone induction, the semen was collected using a conical tube of $15 \mathrm{~mL}$ (one for each animal) while recording the volume of samples and avoiding contamination by feces or urine (Billard et al., 1995). Immediately after the collection, the seminal evaluations were performed. The parameters were analyzed according to (Galo et al., 2011) as follows:

Spermatic motility: the spermatic motility was observed through optical microscopy (40X) by diluting 20:400 $\mu \mathrm{L}$ (semen:distilled water) in a slide under a coverslip and was classified with a score from 0 to $100 \%$.

Motility time: a chronometer was used after the dilution $(20: 400 \mu \mathrm{L}$ of semen:distilled water) to analyze the spermatic motility. The time until the last spermatozoid stopped moving in the optical field (40X) was recorded.

Using the dilution of 1:1000 (semen:formaldehyde-saline buffered solution), extensions were produced and colored by the Rose Bengal Method (Streit-Junior et al., 2004), and 100 spermatozoids extension $^{-1}$ animal $^{-1}$ were counted through optical microscopy with phase contrast (40X). Primary abnormalities were considered to be a broken tail, rolled tail, and degenerated tail, while the secondary abnormalities were a free head, free tail, and rolled tail.

\subsection{Semen cryopreservation}

After spermatic evaluations, the fresh semen was crypreserved in a diluted solution based on Beltsville Thawing Solution (BTS) (Pursel and Johnson, 1975). 
The cryopreserved solution was composed by using BTS with $8 \%$ Dimethyl-Sulfoxide DMSO (Varela Junior et al., 2012). The semen and the cryopreserved solution were homogenized at a proportion of 1:4 (semen:solution), bottled in identified $0.25 \mathrm{~mL}$ straws, and stored in a dry shipper cylinder (Taylor-Wharton, model CP 300 dry shipper) for subsequent cooling. After $24 \mathrm{~h}$ in the dry shipper, the semen was transferred to the liquid nitrogen cylinder (MVE, model CP-34) (Taitson et al., 2008) and stored for 15 days.

\subsection{Thawing and analyses of cryopreserved semen}

One straw with cryopreserved semen was thawed by immersion in a water-bath $\left(45^{\circ} \mathrm{C} 5\right.$ seconds $\left.^{-1}\right)$ (Streit-Junior et al., 2006) for spermatic motility, motility time, and morphology of spermatozoids analyses (Galo et al., 2011).

The mitochondrial functionality analysis was performed through fluorescent coloration by adding $10 \mu \mathrm{L}$ of thawed semen with $40 \mu \mathrm{L}$ work solution of Rhodamine $123(13 \mu \mathrm{M})$ and incubating the mixture at $20{ }^{\circ} \mathrm{C} 10 \mathrm{~min}^{-1}$ (Varela Junior et al., 2012). The DNA integrity was evaluated by using anacridine orange catheter and adding $45 \mu \mathrm{L}$ of thawed semen in $50 \mu \mathrm{L}$ TNE $(0.01 \mathrm{M}$ Tris-HCl, $0.15 \mathrm{M} \mathrm{NaCl}$, $0.001 \mathrm{M}$ EDTA, and $\mathrm{pH} 7.2$ ); after 30 seconds, $200 \mu \mathrm{L}$ of Triton solution (1X) was added. After another 30 seconds, $50 \mu \mathrm{L}$ of acridine orange ( $2 \mathrm{mg}$ per $\mathrm{mL}$ in deionized water) was added, and after 5 minutes, the sample was evaluated without exceeding 1 minute of exposition. Through the use of acarboxy fluoresce indiacetate fluorescent catheter (CDFC) and propidium iodine (PI), the membrane integrity of the spermatozoids was obtained by adding $10 \mu \mathrm{L}$ of thawed semen and $40 \mu \mathrm{L}$ of work solution incubated at $20{ }^{\circ} \mathrm{C} 10$ minutes $^{-1}$. The mitochondrial functionality, integrity of DNA, integrity of spermatic membrane, and cell feasibility for semen of tambaqui were analyzed according to (Billard et al., 1995) by using anepifluorescence microscope (Olympus ${ }^{\circledR}$ BX 51, America INC, São Paulo, Brazil) to evaluate 200 cells sample ${ }^{-1}$ from $1 \mu \mathrm{L}$ of solution with spermatozoids in microscopic slide under a cover slip. The rates were expressed through the percentage of integral/functional cells compared to the total number of cells.

\subsection{Reproductive efficiency test}

The cell feasibility was obtained by using eosin-nigrosin histochemical dye, and the protocol was adapted from (Morrison et al., 1997). A fraction of $10 \mu \mathrm{L}$ of semen diluted in BTS was added to $10 \mu \mathrm{L}$ of coloration solution (1.6 $\mathrm{g}$ Eosin Y and $6 \mathrm{~g}$ nigrosin BTS), was homogenized, and after 2 minutes, the smear was performed. After the slide was dry, the spermatozoids were observed in a light field (BX41 Olympus ${ }^{\circledR}$ ) with the oil immersion objective $(100 \mathrm{x})$, and the dead spermatozoids were colored in red.

When evaluating the use of cryopreserved semen on the fertilization and hatching rates of 27 animals, the semen samples were divided into two groups: 1) Semen from 10 animals that fertilized oocytes of 3 females; 2 ) Semen from 17 animals that fertilized oocytes of 3 new females, there by leading to a total of 30 and 51 combinations (semen $\times$ oocytes). A $0.25 \mathrm{~mL}$ pellet was utilized for each $2 \mathrm{~g}$ aliquot of oocytes, which were homogenized, activated, and hydrated with $8 \mathrm{~mL}$ of water. Another two aliquots of oocytes were fertilized with fresh semen collected from two other males at the same time (control with fresh semen), thereby adding up to 83 combinations. For these samples, $50 \mu \mathrm{L}$ of fresh semen were utilized so the number of spermatic cells oocytes ${ }^{-1}$ would be equal to that of the frozen treatments that were already diluted.

After fertilization, the eggs were deposited in 3-liter incubators individualized for each combination (semen $\times$ oocytes), and after $6 \mathrm{~h}$ of incubation $\left(\mathrm{T}=28 \pm 1^{\circ} \mathrm{C}\right.$ ), an aliquot of the eggs from each incubator was removed and the fertilization rate was measured. This operation was performed three times while counting 100 eggs/sample, and thus, the mean was the fertilization rate. After $12 \mathrm{~h}$ of measuring the fertilization rate at the mean water temperature of $28 \pm 1{ }^{\circ} \mathrm{C}$, visual counting of the hatching rate was performed, where all viable larvae and eggs were counted to determine the percentage.

\subsection{Protein analysis}

A $200 \mu \mathrm{L}$ sample of semen from each animal was diluted in $800 \mu \mathrm{LBTS}$ and centrifuged at $800 \mathrm{rpm}$ (rotation/minute), after which the residue (spermatozoids) was discarded and only the supernatant (seminal plasma - proteins) was cryopreserved in liquid nitrogen. After thawing, the supernatant was re-centrifuged at $10.000 \times \mathrm{g} 10 \mathrm{~min}^{-1}$ to obtain only the seminal plasma. From the plasma, a $10 \mu \mathrm{L}$ aliquot was removed and $30 \mu \mathrm{L}$ of deionized water and $20 \mu \mathrm{L}$ of sample buffer were added; the buffer consisted of $20 \%$ glycerol, 10\% Tris-HCl 0.6173 M, pH 6.8 (Gibco-Invitrogen, Grand Island, NY, USA), 2\% $\beta$-Mercaptoethanol (Sigma Aldrich, St. Louis, MO, USA), 20\% Dodecilsodium sulfate at $10 \%$ - SDS (Fisher Scientific, Suwanee, GA - USA), $2.5 \mathrm{mg}$ bromophenol blue (Synth, Diadema, Sao Paulo, Brazil), and deionized water. Then, the samples were heated at $100{ }^{\circ} \mathrm{C} 10 \mathrm{~min}^{-1}$ for protein denaturation. The one-dimensional electrophoresis (SDS-PAGE) was performed through the BIORAD Mini-Protean $3 \mathrm{Cell}^{\circledR}$ system (Bio-Rad Laboratories, California, USA) according to (Laemmli, 1970) in polyacrylamide gels (Gibco-Invitrogen, Grand Island, NY, USA). It was concentrated at 8 and $15 \%$ (Maňásková and Jonáková, 2008) and the molecular marker Bench Mark Protein Ladder ${ }^{\circledR}$ (Gibco-Invitrogen, Grand Island, NY, USA) was utilized. The gels were colored with Coomassie Brilliant Blue (Bio-Rad Laboratories, California, USA) for 20 minutes (Syntin et al., 1996). The discolored process of the gels was obtained by using a discolored solution consisting of $40 \%$ methanol (Synth, Diadema, São Paulo, Brazil), 10\% glacial acetic acid (Synth, Diadema, São Paulo, Brazil), and 50\% deionized water for $1 \mathrm{~h}$ in a water bath at $75^{\circ} \mathrm{C}$. The analysis was based on the visualization and distinction of protein bands formed during electrophoresis. Data obtained from electrophoresis was analyzed by TotalLab TL100 ${ }^{\circledR}$ software, version 2006 (Nonlinear Dynamics, UK). 


\subsection{Spermatozoid ultrastructural analysis: Transmission Electronic Microscopy (TEM)}

Samples of semen (fresh and frozen) from each animal were fixed in $2.5 \%$ glutaraldehyde in a phosphate buffer $(0.1 \mathrm{M}, \mathrm{pH} 7.2)$ and post fixed in $1 \%$ osmium tetroxide in a phosphate buffer $(0.1 \mathrm{M}, \mathrm{pH} 7.2)$ for $3 \mathrm{~h}$. After dehydration, the material was included in araldite (Durcupan ACM, Fluka, Sigma-Aldrich, St. Louis, USA), and after, $0.5 \mu \mathrm{m}$ sections were colored with toluidine blue for the choice of the area to be evaluated Then, sections between 50 to $70 \mathrm{~nm}$ were contrasted in uranyl acetate and lead citrate for further analysis and photo documentation through electronic microscopy transmission, mark CM100 (Eindhoven, The Netherlands).

\subsection{Statistical analysis}

A normality analysis was performed through the Shapiro-Wilktest for all variables, for which all variables had a parametric behavior. Thus, a variance analysis (ANOVA) was preceded with a subsequent comparison among means using the Tukey test. For these analyzes were considered at a significance level of 0.05 .

\section{Results}

The spermatic parameters recorded for fresh and cryopreserved semen with DMSO of C. macropomum are summarized in Table 1.

When considering all collections, the SDS-PAGE identified 11 protein bands in the $8 \%$ polyacrylamide gel $(12,25,29,34,37,44,50,65,75,90$, and $100 \mathrm{kDa})$ and 4 bands in the $15 \%$ polyacrylamide gel $(40,70,78$, and $85 \mathrm{kDa})$, totaling 15 bands in the seminal plasma of tambaqui C. macropomum (Figure 1).

When the interaction (presence or absence) of proteins found in the seminal plasma and the spermatic parameters of C. macropomum frozen with DMSO was evaluated, an effect of proteins on spermatic quality was observed (Tables 2 and 3 ).

The majority of the proteins in the seminal plasma of $C$. macropomum positively influenced $(\mathrm{P}<0.05)$

Table 1. Seminal parameters of fresh and cryopreserved semen from Colossoma macropomum.

\begin{tabular}{|c|c|c|}
\hline \multirow{2}{*}{ PARAMETERS } & \multicolumn{2}{|c|}{ SEMEN } \\
\hline & Fresh & Cryopreserved \\
\hline Spermatic motility (\%) & $87.50 \pm 12.25$ & $14.40 \pm 9.15$ \\
\hline Motility time (seconds) & $50.75 \pm 81.90$ & $30.60 \pm 10.71$ \\
\hline Normal spermatozoids (\%) & $31.90 \pm 1.72$ & $22.23 \pm 1.72$ \\
\hline Total abnormalities (\%) & $68.12 \pm 1.72$ & $77.77 \pm 9.07$ \\
\hline Primary abnormalities (\%) & $50.00 \pm 2.72$ & $55.76 \pm 10.25$ \\
\hline Secondary abnormalities (\%) & $18.12 \pm 2.58$ & $22.01 \pm 7.90$ \\
\hline Fertilization rate $(\%)$ & $87.67 \pm 15.81$ & $26.73 \pm 13.57$ \\
\hline Hatching rate $(\%)$ & $83.25 \pm 23.60$ & $27.65 \pm 16.76$ \\
\hline DNA integrity (\%) & - & $95.43 \pm 3.96$ \\
\hline Membrane integrity (\%) & - & $55.18 \pm 18.39$ \\
\hline Mitochondrial functionality (\%) & - & $53.83 \pm 30.01$ \\
\hline Cell feasibility $(\%)$ & - & $19.22 \pm 16.91$ \\
\hline
\end{tabular}

Mean \pm SEM (standard error).

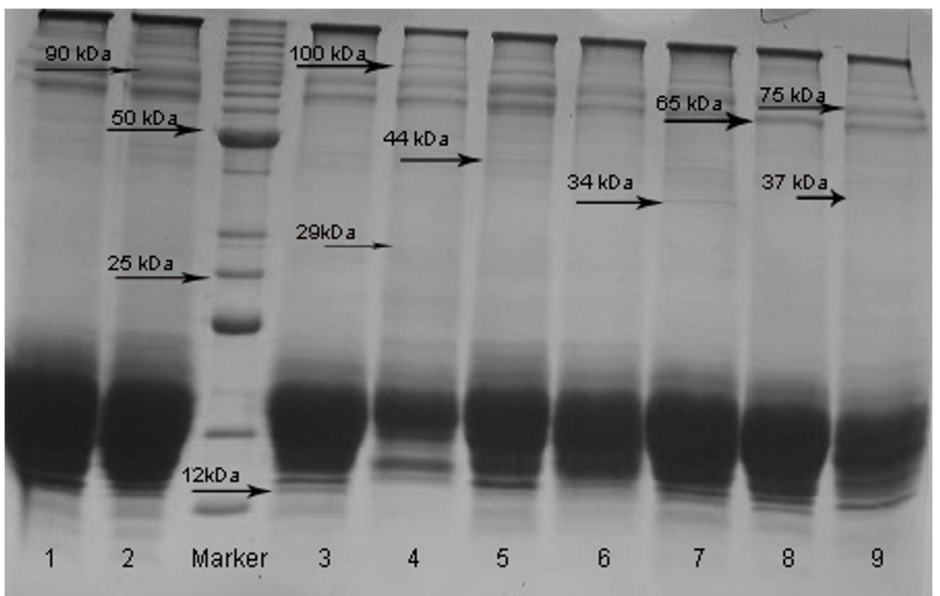

Figure 1. Electrophoresis of polyacrylamide gel (8\% SDS-PAGE colored with Coomassie blue) of seminal plasma from Colossoma macropomum showing 9 animals (with molecular weight from 12 to $100 \mathrm{kDa}$ ). 


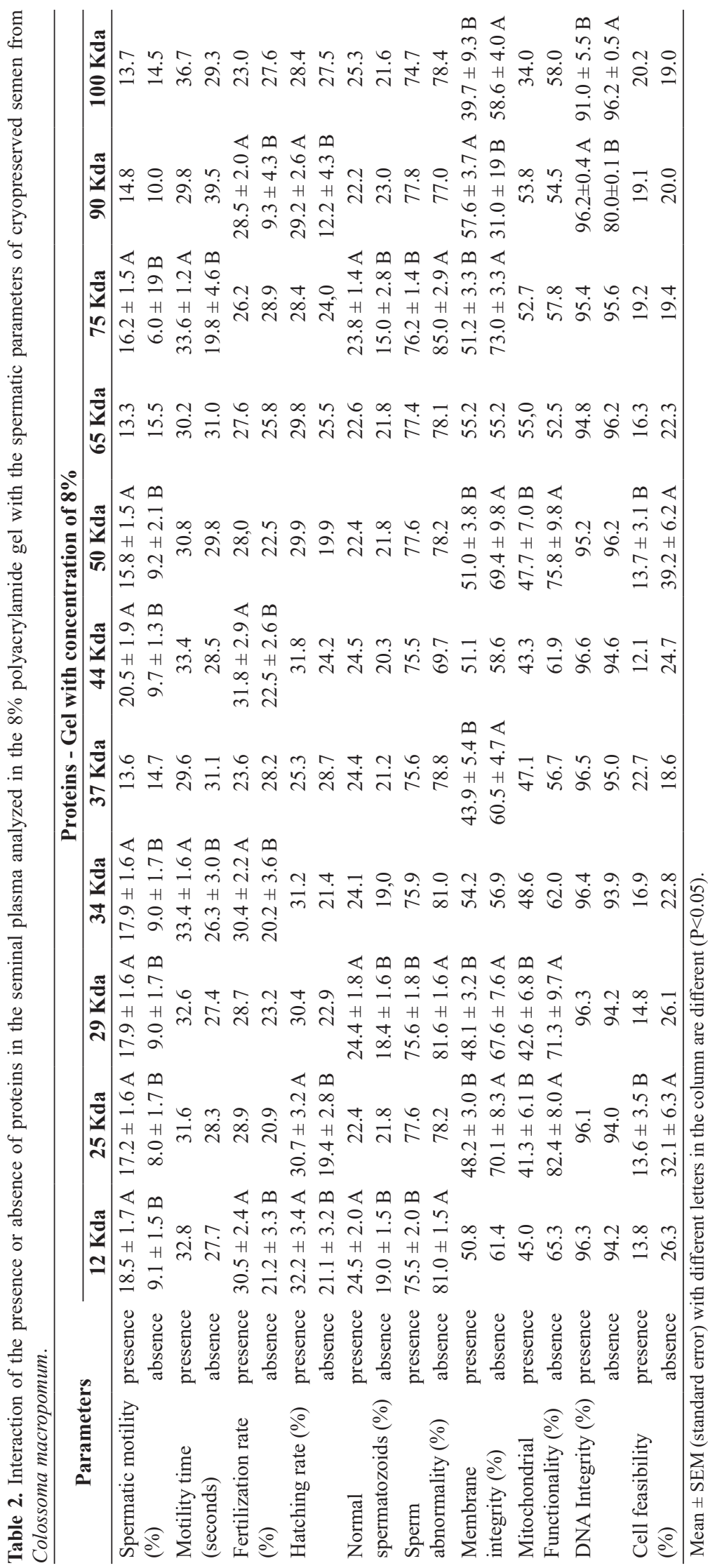


Table 3. Interaction of the presence or absence of proteins in the seminal plasma analyzed in the $15 \%$ polyacrylamide gel with the spermatic parameters of cryopreserved semen from Colossoma macropomum.

\begin{tabular}{llcccc}
\hline \multirow{2}{*}{ Parameters } & & \multicolumn{3}{c}{ Proteins - Gel with concentration of 15\% } \\
\cline { 3 - 5 } & & $\mathbf{4 0 ~ K d a}$ & $\mathbf{7 0 ~ K d a}$ & $\mathbf{7 8 ~ K d a ~}$ & $\mathbf{8 5 ~ K d a ~}$ \\
\hline Spermatic motility (\%) & presence & 17.5 & 15.0 & 13.4 & 15.0 \\
& absence & 13.7 & 14.2 & 19.0 & 13.3 \\
Motility time (seconds) & presence & 30.5 & 32.8 & 30.2 & 31.3 \\
& absence & 30.6 & 30.0 & 32.7 & 29.2 \\
Fertilization rate (\%) & presence & 31.6 & 32.2 & 26.8 & $29.5 \pm 2.3 \mathrm{~A}$ \\
& absence & 25.6 & 25.1 & 26.4 & $20.7 \pm 3.8 \mathrm{~B}$ \\
Hatching rate (\%) & presence & $38.8 \pm 3.5 \mathrm{~A}$ & 35.9 & 27.5 & 30.1 \\
Normal spermatozoids & presence & 20.5 & 25.2 & 28.5 & 22.5 \\
(\%) & absence & 22.6 & 18.8 & 21.3 & 21.5 \\
Sperm abnormality (\%) & presence & 79.5 & 23.2 & 78.5 & 23.7 \\
& absence & 77.4 & 81.2 & 73.5 & 78.5 \\
Membrane integrity (\%) & presence & 50.5 & 76.8 & 54.2 & 76.3 \\
& absence & 56.2 & 55.4 & 61.0 & 54.5 \\
Mitochondrial & presence & 48.7 & 53.9 & 56.0 & 56.4 \\
Functionality (\%) & absence & 54.9 & 50.2 & 43.5 & 55.3 \\
DNA Integrity (\%) & presence & 96.5 & 54.8 & 95.8 & 51.0 \\
Cell viability (\%) & absence & 95.2 & 96.4 & 93.3 & 95.1 \\
& presence & 14.5 & 95.1 & 21.4 & 96.2 \\
\hline
\end{tabular}

Mean \pm SEM (standard error) with different letters in the column differed $(\mathrm{P}<0.05)$.

the progressive motility of frozen semen with DMSO (Table 2). As a consequence, a greater fertilization rate was observed with the presence of the following proteins: $12,34,44,85$, and $90 \mathrm{kDa}$. However, the hatching rate was improved $(\mathrm{P}<0.05)$ only with the presence of proteins $12,25,40$, and $90 \mathrm{kDa}$.

The percentage of normal spermatozoids (\%) in thawed semen of $C$. macropomum was greater $(\mathrm{P}<0.05)$ with the presence of proteins 12,29 , and $75 \mathrm{kDa}$ in the seminal plasma, thus reflecting the percentage of total spermatic abnormalities.

For DNA integrity, the presence of heavier proteins such as 90 and $100 \mathrm{kDa}$ demonstrated an interaction with seminal parameters post thawing, with the greatest and lowest $(\mathrm{P}<0.05)$ DNA integrity, respectively. For membrane integrity $(\%)$ and mitochondrial functionality $(\%)$, greater $(\mathrm{P}<0.05)$ percentages for these spermatic parameters were recorded with the absence of proteins 25, 29, 37, 50, 75, and $100 \mathrm{kDa}$. The absence of the proteins 25 and $50 \mathrm{kDa}$ positively influenced the cell feasibility of the spermatozoids.

The presence of the protein $12 \mathrm{kDa}$ affected $(\mathrm{P}<0.05)$ the progressive motility, percentage of normal and abnormal spermatozoids, and consequently, the fertilization and hatching rates. The interaction $(\mathrm{P}<0.05)$ with motility time (seconds) was observed only for the proteins 34 and $75 \mathrm{kDa}$, while the proteins 65,70 , and $78 \mathrm{kDa}$ did not influence $(\mathrm{P}>0.05)$ the parameters of cryopreserved semen of C. macropomum.
Table 4. Frequency distribution (\%) of the protein bands detected through SDS-PAGE in seminal plasma of Colossoma macropomum.

\begin{tabular}{ccc}
\hline Bands & $\begin{array}{c}\text { Molecular weight } \\
\text { (kDa) }\end{array}$ & $\begin{array}{c}\text { Frequency of bands } \\
\text { (\%) in 27 samples }\end{array}$ \\
\hline 1 & 12 & $40.7(11)$ \\
2 & 25 & $33.3(9)$ \\
3 & 29 & $40.7(11)$ \\
4 & 34 & $40.7(11)$ \\
5 & 37 & $66.7(18)$ \\
6 & 40 & $81.5(22)$ \\
7 & 44 & $59.3(16)$ \\
8 & 50 & $18.5(5)$ \\
9 & 65 & $44.4(12)$ \\
10 & 70 & $77.8(21)$ \\
11 & 75 & $18.5(5)$ \\
12 & 78 & $22.2(6)$ \\
13 & 85 & $40.7(11)$ \\
14 & 90 & $14.8(4)$ \\
15 & 100 & $77.8(21)$ \\
\hline
\end{tabular}

Samples within parentheses: number of animals that presented with the protein.

No protein was observed in the samples of the seminal plasma. Only the protein $40 \mathrm{kDa}$ was verified in $81.5 \%$ of the samples. However, the protein $90 \mathrm{kDa}$ was observed in four samples $(14.8 \%)$ (Table 4$)$. 


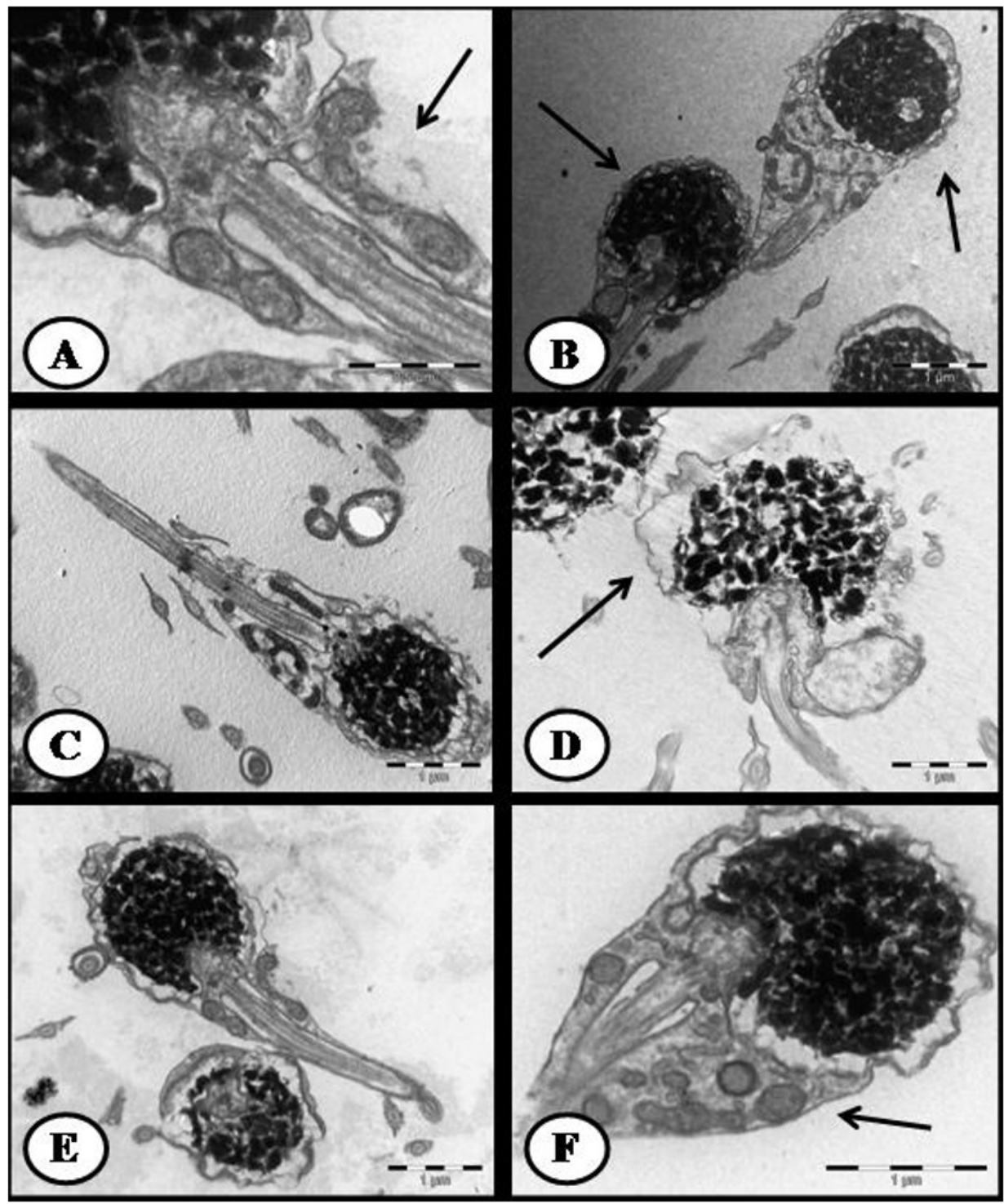

Figure 2. Illustrations of morphology obtained by electronic microscopy transmission of the cryopreserved spermatozoids of Colossoma macropomum. (A) and (E) broken membrane in the intermediate piece; (B) and (C) membrane of the integral head; (D) broken membranes in the head and intermediate pieces; (F) integral mitochondria.

The frequencies of the proteins 29 and $75 \mathrm{kDa}$ in the semen samples were 40.7 and $18.5 \%$, respectively. Thus, $55.2 \%$ of the spermatozoids were observed with full membranes, while $53.8 \%$ of the spermatozoids were observed with mitochondrial functionality in the semen of C. macropomum after thawing (Figure 2).

\section{Discussion}

Currently, several proteins of seminal plasma have been identified and characterized (Moreau and Manjunath, 1999), and others have been associated with fertility in different species (Ayyagari et al., 1987; Kraus et al., 2001). The identification of the proteins in the seminal plasma has an important merit because it can be used to predict, increase, and prevent (preservative) fertility (Killian et al., 1993).

The correlation between proteins of the seminal plasma and fertility of males was demonstrated for some species of domesticated animals such as bulls (Killian et al., 1993), rams (Jobim et al., 2005), goats (Villemure et al., 2003), stallions, and hogs (Calvete et al., 1997). The presence of protein factors in the seminal plasma was described for several species of fish, such as Oreochromis niloticus (Mochida et al., 2002), Oncorynchus mykiss (Loir et al., 1990; Lahnsteiner et al., 2004; Lahnsteiner, 2007a), and Cyprinus carpio (Kowalski et al., 2003). In some studies (Mochida et al., 1999; Lahnsteiner et al., 2004; Lahnsteiner, 
2007a), the identified protein factors were associated with parameters of sperm quality. However, there is little information regarding the proteins of seminal plasma for Brazilian native fishes (Campos et al., 2006).

In the present study, despite the fact that the motility time was greater only for the presence of proteins 34 and $75 \mathrm{kDa}$, the majority of the proteins with a molecular weight equal to or less than $50 \mathrm{kDa}(12,25,29,34,44$, and $50 \mathrm{kDa})$ were associated with an improvement in the progressive motility of the semen after thawing. This fact agrees with the report of (Lahnsteiner et al., 2004) who observed that the dilutor vehicle containing PSP (proteins of the seminal plasma) of Oncorynchus mykiss with a molecular weight $<50 \mathrm{kDa}$ results in higher motility and spermatic speed rates when compared to a dilutor containing proteins with a molecular weight $>50 \mathrm{kDa}$.

In the semen of C. macropomum, the 12,29 , and $75 \mathrm{kDa}$ proteins demonstrated an interaction with other qualitative parameters (normal spermatozoids and spermatic abnormalities) of the semen. According to (Frazer et al., 1996), the presence of PSP in mammals, with the apparent molecular weight of 19.6 and $15.3 \mathrm{kDa}$, was related to the increase in progressive motility of the fresh and thawed sperm. Souza et al. (2007) focused on the effects of proteins with greater molecular weight such as $75 \mathrm{kDa}$, in the semen of C. macropomum, they studied the correlation between the characteristics of semen from dogs with the proteins of seminal plasma, and identified a positive correlation between bands 58.6 and $67 \mathrm{kDa}$ with the percentage of normal spermatozoids.

The mitochondrial functionality, membrane integrity, and DNA integrity of the spermatozoids after cryopreservation of C. macropomum improved with the absence of proteins with molecular weights of $25,29,37,50$, and $75 \mathrm{kDa}$, despite the fact that motor activity (motility and motility time) were better in the presence of the same proteins. The absence of the proteins $29,37,50$, and $75 \mathrm{kDa}$ led to an integrity greater than $58 \%$. This fact demonstrates that even though the spermatozoids had good motility, they were not ready to be functional, especially when considering the proteins 25 and $50 \mathrm{kDa}$, for which the cell feasibility was the lowest. According to (Bianchi et al., 2008), when considering in silico database, a protein group was found with a molecular weight of approximately $26 \mathrm{kDa}$ called Sialoproteins that has the ability to inhibit the heads'agglutination of the spermatozoids. According to (Strzeżek et al., 2002), the deficiency of this group can compromise the potential spermatic fertilization. Using two dimensional electrophoresis (2DPAGE), Flowers (2001) demonstrated the biological importance of the proteins $26 \mathrm{kDa}$ and $55 \mathrm{kDa}$ in the seminal plasma of swine in relation to high birth rates (around 86\%). Kraus et al. (2001) associated four proteins from the seminal plasma with bull fertility, as two proteins ( 26 and $55 \mathrm{kDa}$ ) were detected in highly fertile bulls.

The significant increase of cell destruction of the spermatozoid is a factor highly associated with the process of cryopreservation; thus, it is possible to identify a change in membrane integrity and mitochondrial functionality. In cattle, there are proteins of seminal plasma (PSP) that participate in lipid sequester deconstructing of the membrane, which increases its fluid capacity. Then, those proteins associate with the membrane of the spermatozoid sat the time of ejaculation, thereby inducing the efflux of cholesterol and phospholipids from the spermatic membrane, which can induce the non-stabilization and decrease its stability for the process of semen cryopreservation that is currently utilized (Therien et al., 1999).

The expression of the protein with a greater molecular weight $(100 \mathrm{kDa})$ did not help either the membrane or DNA integrities. In the seminal plasma of pigs, Corcini et al. (2012) observed that the $100 \mathrm{kDa}$ protein was also associated with a reduction in membrane integrity of fresh semen, and a reduction in motility after freezing. When the second heaviest molecular protein $(90 \mathrm{kDa})$ is analyzed, despite the fact that motility and motility time were not positively altered, its presence in the semen after cryopreservation of C. macropomum resulted in a significant gain in the results regarding fertilization and hatching rates. Also, we have to highlight the fact that the membrane integrity and mitochondrial functionality rates were the unique positive parameters in the presence of the $90 \mathrm{kDa}$ protein. An interesting fact relates to the incidence of animals that expressed the $90 \mathrm{kDa}$ protein, as it was the lowest for all observations (only 4 from the total - approximately $15 \%$ ).

The good results for the seminal quality associated with the $25 \mathrm{kDa}$ protein in terms of plasmatic membrane integrity can be explained by the finds reported by (Bianchi et al., 2008). In this case, the authors relayed that in situ database, a protein group was observed with a molecular weight of approximately $26 \mathrm{kDa}$ called Sialoproteins that have the ability to inhibit the agglutination of heads from the spermatozoids. According to Strzeżek et al. (2005), the deficiency of this group can compromise the potential spermatic fertilization. Using two dimensional electrophoresis (2DPAGE), Flowers (2001) illustrated the biological importance of the proteins 26 and $55 \mathrm{kDa}$ in the seminal plasma of swine in relation to high birth rates (around 86\%). Killian et al. (1993) associated four proteins of the seminal plasma with bull fertility, since two proteins $(26$ and $55 \mathrm{kDa}$ ) were detected in highly fertile bulls. The protein found in the present study $(25 \mathrm{kDa})$ was the protein associated with the hatching rate, such as the proteins 40 and $90 \mathrm{kDa}$. Also, the $90 \mathrm{kDa}$ protein was associated with DNA integrity. Asadpour et al. (2007) reported that in buffalo, the protein with $55 \mathrm{kDa}$ was associated with feasibility of fresh semen. In this study, the proteins that demonstrated an association with cell feasibility of semen after thawing were 25 and $50 \mathrm{kDa}$.

Therefore, more detailed studies regarding the function of PSPs are necessary to elucidate the implications of the individual effects, as well as the influence of other factors such as season, nutrition, and age. The identification of potential markers related to fertility parameters should be important for breeding selection in programs using artificial 
fertilization with frozen semen and for the formation of a germ plasma database of selected animals.

The proteins of the seminal plasma from C. macropomum influenced spermatic quality after thawing and can be utilized as markers for spermatic quality, especially the proteins with molecular weights lower than $50 \mathrm{kDa}$, such as the proteins 12 , 25, 29, 34, 40, 44, and $50 \mathrm{kDa}$. However, the protein $90 \mathrm{kDa}$ despite being the smallest protein found in the seminal plasma of C. macropomum, his presence was the one with the best parameters for sperm quality, in other words, the animal with this protein has a better predisposition to semen freezing.

\section{Acknowledgements}

The Boa Esperança fish farm (Pimenta Bueno-RO) and the Aquabrasil project (Embrapa), for the partnership in the implementation of this study.

\section{References}

AlvareZ, B., ARENAL, A., FUENTES, R., PIMENTEL, R., ABAD, Z. and PIMENTEL, E., 2008. Use of post-thaw silver carp (Hypophtalmichthys molitrix) spermatozoa to increase hatchery productions. In: E. CABRITA, V. ROBLES and M.P. HERRAÉZ, eds. Methods in reproductive aquaculture: marine and freshwater species. Boca Raton: CRC Press, pp. 345-350. Biology Series.

ASADPOUR, R., ALAVI-SHOUSHTARI, S.M., REZAII, S.A. and ANSARI, M.H.K., 2007. SDS polyacrylamide gel electrophoresis of buffalo bulls seminal plasma proteins and their relation with semen freezability. Animal Reproduction Science, vol. 102, no. 3-4, pp. 308-313. http://dx.doi.org/10.1016/j. anireprosci.2007.03.003. PMid:17433580.

AUTIERO, M., SANSONE, G. and ABRESCIA, P., 1991. Relative ratios oflactoferrin, albumin, and acid phosphatase seminal levels as sperm quality markers in fertile and infertile men. Journal of Andrology, vol. 12, no. 3, pp. 191-200. PMid:1917683.

AYYAGARI, R.R., FAZLEABAS, A.T. and DAWOOD, M.Y., 1987. Seminal plasma proteins of fertile and infertile men analyzed by two-dimensional electrophoresis. American Journal of Obstetrics and Gynecology, vol. 157, no. 6, pp. 1528-1533. http://dx.doi.org/10.1016/S0002-9378(87)80257-0. PMid:3425658.

BIANCHI, I., COLLARES, T., CAMPOS, V.F., CAVALCANTI, P.V., KAEFER, C., CORREAA, E.K., DELLAGOSTIN, O.A., LUCIA JUNIOR, J.R., DESCHAMPS, J.C. and CORREA, M.N., 2008. Fator do plasma seminal associado à integridade de membrana de espermatozoides suínos pós-descongelamento. Arquivo Brasileiro de Medicina Veterinária e Zootecnia, vol. 60, no. 2, pp. 384-388. http://dx.doi.org/10.1590/S0102-09352008000200017.

BILLARD, R., COSSON, J., PERCHEC, G. and LINHART, O., 1995. Biology of sperm and artificial reproduction in carp. Aquaculture, vol. 129, no. 1-4, pp. 95-112. http://dx.doi. org/10.1016/0044-8486(94)00231-C.

BRASIL. Ministério de Pesca e Aquicultura, 2013. Boletim estatístico. Brasilia.

CALVETE, J.J., RAIDA, M., GENTZEL, M., URBANKE, C., SANZ, L. and TÖPFER-PETERSEN, E., 1997. Isolation and characterization of heparin- and phosphorylcholine-binding proteins of boar and stallion seminal plasma. Primary structure of porcine pB1. FEBS Letters, vol. 407, no. 2, pp. 201-206. http:// dx.doi.org/10.1016/S0014-5793(97)00344-X. PMid:9166899.

CAMPOS, V.F., CAVALCANTI, P.V., KAEFER, C., SILVA, E.S., SEIXAS, F.K., AMARAL, M.G., LUCIA JUNIOR, T., DESCHAMPS, J.C. and COLLARES, T., 2006. Comparação entre proteínas presentes no plasma seminal de jundiás (Rhamdia quelen) cultivados e selvagens. In: Anais do XV Congresso de Iniciação Cientifica e VIII Encontro de Pós-graduação, 2006, Pelotas. Pelotas: UFPEL.

CIERESZKO, A., GLOGOWSKI, J. and DABROWSKI, K., 2000. Biochemical characteristics of seminal plasma and spermatozoa of freshwater fishes. In: T.R. TIERSCH and P.M. MAZIK, eds. Cryopreservation in aquatic species. Baton Rouge: World Aquaculture Society, pp. 20-48.

CORCINI, C., VARELA JUNIOR, A.S., PIGOZZO, R., RAMBO, G., GOULARTE, K.L., CALDERAM, K., LEON, P.M.M., BONGALHARDO, D.C. and LUCIA JUNIOR, T., 2012. Pre-freezing and post-thawing quality of boar sperm for distinct portions of the ejaculate and as a function of protein bands present in seminal plasma. Livestock Science, vol. 145, no. 1-3, pp. 28-33. http://dx.doi.org/10.1016/j.livsci.2011.12.016.

COSSON, J., BILLARD, R., CIBERT, C. and DRÉANNO, C., 1999. Ionic factors regulating the motility of fish sperm in. The Male Gamete, vol. 16, pp. 161-186.

FIGUEROA, E., VALDEBENITO, I., ZEPEDA, A.B., FIGUEROA, C.A., DUMORNE, K., CASTILLO, R.L. and FARIAS, J.G., 2017. Effects of cryopreservation on mitochondria of fish spermatozoa. Reviews in Aquaculture, vol. 9, no. 1, pp. 76-87. http://dx.doi.org/10.1111/raq.12105.

FLOWERS, W.L., 2001. Relationship between seminal plasma proteins and boar fertility. Raleigh: Annual Swine News, pp. 1-4.

FRAZER, G.S., BUCCI, D.M. and BROOKS, C.L., 1996. Twodimensional polyacrylamide gel electrophoresis of bovine semen after cryopreservation in halfmillilitre straws. Theriogenology, vol. 46, no. 7, pp. 1103-1115. http://dx.doi.org/10.1016/S0093691X(96)00283-X. PMid:16727975.

GALO, J.M., STREIT-JUNIOR, D.P., SIROL, R.N., RIBEIRO, R.P., DIGMAYER, M., ANDRADE, V.X.L. and EBERT, A.R., 2011. Spermatic abnormalities of piracanjuba Brycon orbignyanus (Valenciennes, 1849) after cryopreservation. Brazilian Journal of Biology $=$ Revista Brasileira de Biologia, vol. 71, no. 3, pp. 1-7. http://dx.doi.org/10.1590/S1519-69842011000400014. PMid:21881793.

JOBIM, M.I.M., OBERST, E.R., SALBEGO, C.G., SOUZA, D.O., WALD, V.B., TRAMONTINA, F. and MATTOS, R.C., 2004. Two-dimensional polyacrylamide gel electrophoresis of bovine seminal plasma proteins and their relation with semen freezability. Theriogenology, vol. 61, no. 2-3, pp. 255-266. http:// dx.doi.org/10.1016/S0093-691X(03)00230-9. PMid:14662126.

JOBIM, M.I.M., OBERST, E.R., SALBEGO, C.G., WALD, V.B., HORN, A.P. and MATTOS, R.C., 2005. BSP A1/A2 like proteins in RAM seminal plasma. Theriogenology, vol. 63, no. 7, pp. 20532062. http://dx.doi.org/10.1016/j.theriogenology.2004.10.002. PMid: 15823360

KILLIAN, G.J., CHAPMAN, D.A. and ROGOWSKI, L.A., 1993. Fertility-associated proteins in Holstein bull seminal plasma. Biology of Reproduction, vol. 49, no. 6, pp. 1202-1207. http://dx.doi.org/10.1095/biolreprod49.6.1202. PMid:8286602. 
KOWALSKI, R., GLOGOWSKI, J., KUCHARCZYK, D., GORYCZKO, K., DOBOSZ, S. and CIERESZKO, A., 2003. Proteolytic activity and electrophoretic profiles of proteases from seminal plasma of teleosts. Journal of Fish Biology, vol. 63, no. 4, pp. 1008-1019. http://dx.doi.org/10.1046/j.1095-8649.2003.00224.x.

KRAUS, M., TICHA, M. and JONÁKOVÁ, V., 2001. Heparinbinding proteins of human seminal plasma homologous with boar spermadhesins. Journal of Reproductive Immunology, vol. 51, no. 2, pp. 131-144. http://dx.doi.org/10.1016/S0165-0378(01)000729. PMid: 11543852.

LAEMMLI, U.K., 1970. Cleavage of structural proteins during the assembly of the head bacteriophage T4. Nature, vol. 227, no. 5259, pp. 680-685. http://dx.doi.org/10.1038/227680a0. PMid:5432063.

LAHNSTEINER, F., 2007a. Caracterization of plasma proteins stabilizing the sperm viability in raibow trout (Oncorhyncus mykiss). Animal Reproduction Science, vol. 97, no. 1-2, pp. 151-164. http:// dx.doi.org/10.1016/j.anireprosci.2006.01.003. PMid:16464544.

LAHNSTEINER, F., 2007b. Characterization of seminal plasma proteins stabilizing the sperm viability in rainbow trout (Oncorhynchus mykiss). Animal Reproduction Science, vol. 97, no. 1-2, pp. 151-164. http://dx.doi.org/10.1016/j.anireprosci.2006.01.003. PMid:16464544.

LAHNSTEINER, F., 2009. The role of free amino acids in semen of rainbow trout Oncorhynchus mykiss and carp Cyprinus carpio. Journal of Fish Biology, vol. 75, no. 4, pp. 816-833. http://dx.doi. org/10.1111/j.1095-8649.2009.02317.x. PMid:20738581.

LAHNSTEINER, F. and MANSOUR, N., 2010. A comparative study on antioxidant systems in semen of species of the percidae, salmonidae, cyprinidae, and lotidae for improving semen storage techniques. Animal Reproduction Science, vol. 307, pp. 130-140.

LAHNSTEINER, F., MANSOUR, N. and BERGER, B., 2004. Seminal plasma proteins prolong the viability of rainbow trout (Oncorynchus mykiss) spermatozoa. Theriogenology, vol. 62, no. 5, pp. 801-808. http://dx.doi.org/10.1016/j.theriogenology.2003.12.001. PMid:15251231.

LAHNSTEINER, F., MANSOUR, N. and PLAETZER, K., 2010. Antioxidant systems of brown trout (Salmo trutta f. fario) semen. Animal Reproduction Science, vol. 119, no. 3-4, pp. 314-321. http://dx.doi.org/10.1016/j.anireprosci.2010.01.010. PMid:20171027.

LAHNSTEINER, F., PATZNER, R. and WEISMANN, T., 1994. The testicular main duct and the spermatic duct in some cyprinid fishes II: composition of the seminal fluid. Journal of Fish Biology, vol. 44, pp. 459-467.

LOIR, M., LABBÉ, C., MAISSE, G., PINSON, A., BOULARD, G., MOUROT, B. and CHAMBEYRON, F., 1990. Proteins of seminal fluid and spermatozoa of rainbow trout (Oncorhynchus mykiss): partial characterization and variations. Journal Fish Physiology and Biochemistry, vol. 8, no. 6, pp. 485-495. http:// dx.doi.org/10.1007/BF00003405. PMid:24221035.

MAGNOTTI, C., CERQUEIRA, V., LEE-ESTEVEZ, M., FARIAS, J.G., VALDEBENITO, I. and FIGUEROA, E., 2018. Cryopreservation and vitrification of fish semen: a review with special emphasis on marine species. Reviews in Aquaculture, vol. 10, no. 1, pp. 15-25. http://dx.doi.org/10.1111/raq.12145.

MAŇÁSKOVÁ, P. and JONÁKOVÁ, V., 2008. Localization of porcine seminal plasma (PSP) proteins in the boar reproductive tract and spermatozoa. Journal of Reproductive Immunology, vol.
78, no. 1, pp. 40-48. http://dx.doi.org/10.1016/j.jri.2007.10.001. PMid:18031827.

MARIA, A. and CARNEIRO, P., 2012. Fish semen cryopreservation in Brazil: state of the art and future perspectives. Ciência Animal, vol. 22, pp. 124-131.

MOCHIDA, K., KONDO, T., MATSUBARA, T., ADACHI, S. and YAMAUCHI, K., 1999. A high molecular weight glycoprotein in seminal plasma is a sperm immobilizing factor in the teleost nile tilapia, Oreochromis niloticus. Development, Growth \& Differentiation, vol. 41, no. 5, pp. 619-627. http:// dx.doi.org/10.1046/j.1440-169x.1999.00463.x. PMid:10545034.

MOCHIDA, K., MATSUBARA, T., ANDOH, T., URA, K., ADACHI, S. and YAMAUCHI, K., 2002. A novel seminal plasma glycoprotein of a teleost, the nile tilapia (Oreochromis niloticus), contains a partial von willebrand factor type $\mathrm{D}$ domain and a zonapellucida-like domain. Molecular Reproduction and Development, vol. 62, no. 1, pp. 57-68. http://dx.doi.org/10.1002/ mrd.10071. PMid:11933161.

MOREAU, R. and MANJUNATH, P., 1999. Characterization of lipid efflux particles generated by seminal phospholipid-binding proteins. Biochimica et Biophysica Acta, vol. 1438, no. 2, pp. 175-184. http://dx.doi.org/10.1016/S1388-1981(99)00049-9. PMid:10320800.

MORISAWA, M. and SUZUKI, K., 1980. Osmolality and potassium ion: their roles in initiation of sperm motility in teleosts. Science, vol. 210, no. 4474, pp. 1145-1147. http://dx.doi. org/10.1126/science.7444445. PMid:7444445.

MORRISON, S.J., SHAH, N.M. and ANDERSON, D.J., 1997. Regulatory mechanisms in stem cell biology. Cell, vol. 88, no. 3, pp. 287-298. http://dx.doi.org/10.1016/S0092-8674(00)81867-X. PMid:9039255.

PURSEL, V.G. and JOHNSON, L.A., 1975. Freezing of boar spermatozoa: fertilizing capacity with concentrated semen and a new thawing procedure. Journal of Animal Science, vol. 40, no. 1, pp. 99-102. http://dx.doi.org/10.2527/jas1975.40199x. PMid:1110222.

SOUZA, F.F., BARRETO, C.S. and LOPES, M.D., 2007. Characteristics of seminal plasma proteins and their correlation with canine semen analysis. Theriogenology, vol. 68 , no. 1, pp. 100-106. http://dx.doi.org/10.1016/j.theriogenology.2006.11.016. PMid:17512978.

STREIT-JUNIOR, D.P., BENITES, C., MORAES, G.V., RIBEIRO, R.P., SAKAGUTI, E.S. and CALDIERI, R.F., 2006. Sêmen de pacu (Piaractus mesopotamicus) criopreservado com diluentes utilizados para sêmen de suínos. Ciência Animal Brasileira, vol. 7, pp. 289-297.

STREIT-JUNIOR, D.P., MORAES, G.V., RIBEIRO, R.P., POVH, J.A., SOUZA, E.D. and OLIVEIRA, C.A.L., 2004. Avaliação de diferentes técnicas para coloração de sêmen de peixes. Arquivos de Ciência Veterinárias e Zoologia da Unipar, vol. 7, pp. 157-162.

STRZEŻEK, J., SAIZ-CIDONCHA, F., WYSOCKI, P., TYSZKIEWICZ, A. and JASTRZEBSKI, M., 2002. Seminal plasma proteins as markers of biological value of boar semen. Animal Science Papers and Reports, vol. 22, pp. 255-266.

STRZEŻEK, J., WYSOCKI, P., KORDAN, W., KUKLIŃSKA, M., MOGIELNICKA, M., SOLIWODA, D. and FRASER, L., 2005. Proteomics of boar seminal plasma: current studies and possibility of their application in biotechnology of animal 
reproduction. Reproductive Biology, vol. 5, no. 3, pp. 279-290. PMid:16372045.

SYNTIN, P., DACHEUX, F., DRUART, X., GATTI, J.L., OKAMURA, N. and DACHEUX, J.L., 1996. Characterization and identification of proteins secreted in the various regions of the adult boar epididymis. Biology of Reproduction, vol. 55, no. 5, pp. 956-974. http://dx.doi.org/10.1095/biolreprod55.5.956. PMid:8902205.

TAITSON, P.F., CHAMI, E. and GODINHO, H.P., 2008. Gene banking of the neotropical fish Leporinus obtusidens (Valenciennes, 1836): A protocol to freeze its sperm in the field. Animal Reproduction Science, vol. 105, no. 3-4, pp. 283-291. http:/ dx.doi.org/10.1016/j.anireprosci.2007.03.009. PMid:17467933.

THÉRIEN, I., MOREAU, R. and MANJUNATH, P., 1999. Bovine seminal plasma phospholipid-binding proteins stimulate phospholipid efflux from epididymal sperm. Biology of Reproduction, vol. 61, no. 3, pp. 590-598. http://dx.doi.org/10.1095/biolreprod61.3.590. PMid:10456833.

TIERSCH, T., 1995. Cryopreservation of fish sperm: laboratory, hatchery and field studies of twenty species. In: F.W. JULY GOETZ and P. THOMAS, eds. Proceedings of the Fish International
Symposium on the Reproductive Physiology of Fish, 1995, Austin. Austin: University of Texas, pp. 2-8.

TIERSCH, T.R., 2011. Introduction to the second edition. In: T.R. TIERSCH and C.C. GREEN, eds. Cryopreservation in aquatic species. 2nd ed. Baton Rouge: World Aquaculture Society, pp. 1-17.

VARELA JUNIOR, A.S., CORCINI, C.D., GHELLER, S.M., JARDIM, R.D., LUCIA JUNIOR, T., STREIT-JUNIOR, D.P. and FIGUEIREDO, M.R., 2012. Use of amides as cryoprotectants in extenders for frozen sperm of tambaqui, Colossoma macropomum. Theriogenology, vol. 78, no. 2, pp. 244-251. http://dx.doi. org/10.1016/j.theriogenology.2012.02.029. PMid:22578629.

VILLEMURE, M., LAZURE, C. and MANJUNATH, P., 2003. Isolation and characterization of gelatin-binding proteins from goat seminal plasma. Reproductive Biology and Endocrinology, vol. 1, no. 1, pp. 39-50. http://dx.doi.org/10.1186/1477-7827-139. PMid:12737634.

ZILLI, L., SCHIAVONE, R., ZONNO, V., ROSSANO, R., STORELLI, C. and VILELLA, S., 2005. Effect of cryopreservation on sea bass sperm proteins. Biology of Reproduction, vol. 72, no. 5, pp. 1262-1267. http://dx.doi.org/10.1095/biolreprod.104.036202. PMid:15659707. 